\title{
sciendo
}

Current Issues in Pharmacy and Medical Sciences

Formerly ANNALES UNIVERSITATIS MARIAE CURIE-SKLODOWSKA, SECTIO DDD, PHARMACIA

\section{In vitro evaluation of anticancer activity of sodium hyaluronate-titanium dioxide bionanocomposite}

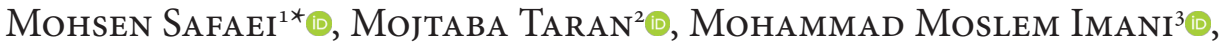

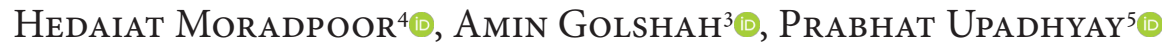

${ }_{1}^{1}$ Advanced Dental Sciences Research Laboratory, School of Dentistry, Kermanshah University of Medical Sciences, Kermanshah, Iran
2 Department of Nanobiotechnology, Faculty of Science, Razi University, Kermanshah, Iran
${ }^{3}$ Department of Orthodontics, School of Dentistry, Kermanshah University of Medical Sciences, Kermanshah, Iran
${ }^{4}$ Department of Prosthodontics, School of Dentistry, Kermanshah University of Medical Sciences, Kermanshah, Iran
${ }^{5}$ Department of Pharmacology, Institute of Medical Sciences, Banaras Hindu University, Varanasi, Uttar Pradesh, India

\section{ARTICLE INFO}

Received 16 September 2018

Accepted 11 March 2019

\section{Keywords:}

Anticancer,

nanocomposite,

Taguchi method,

$\mathrm{TiO}_{2}$ nanoparticles,

sodium hyaluronate,

biopolymer.

\begin{abstract}
The purpose of the current research is to optimize the synthesis of sodium hyaluronatetitanium dioxide nanocomposite with the highest anticancer activity. To this end, the Taguchi method was followed to design nine experiments with different ratios of sodium hyaluronate biopolymer, titanium dioxide nanoparticles and stirring times. The results of scanning electron microscopy (SEM) confirmed the synthesis of the nanoparticle and nanocomposite. The comparison of anticancer activity level of synthesized nanocomposites using MTT assay showed that the nanocomposite synthesized in the conditions of experiment $9(8 \mathrm{mg} / \mathrm{ml}$ of titanium dioxide nanoparticles, $2 \mathrm{mg} / \mathrm{ml}$ of sodium hyaluronate biopolymer and $60 \mathrm{~min}$ stirring time) had the maximum anticancer activity against Michigan Cancer Foundation-7 (MCF-7) cell line. According to the results, the Taguchi method can be employed as an effective and useful strategy to save time and cost in order to determine the optimal conditions for the synthesis of sodium hyaluronate-titanium dioxide nanocomposite with the most favorable anticancer activity.
\end{abstract}

\section{INTRODUCTION}

Given the dramatic medical advances in the treatment strategies over the past decades, researchers have not yet succeeded in treating some diseases such as AIDS [1], autoimmune diseases [2], microbial infections [3], chronic pain [4] and cancer [5,6]. Cancer refers to a set of diseases resulting from uncontrolled cell proliferation. Researchers have already introduced various factors disrupting cell activity, including genetic factors, radioactive substances, chemicals, toxic materials, or overexposure to radiation like sunlight [7]. Cancer is one of the prevalent diseases in the modern world that increasingly affects people. Globally, now, about one out of six deaths are due to cancer. The cancer deaths worldwide are projected to reach over 11 million people by $2030[8,9]$.

In recent years, the use of nanotechnology has opened a promising window for cancer treatment. Nanoparticles (NPs) can be produced from a wide range of materials, most commonly, silicates, non-oxide ceramics and metal oxides.
Lately, metal oxides have been considered for pharmaceutical application in humans due to their sustainability in different conditions $[10,11]$. Among the metal oxides considered in the treatment of cancer is titanium dioxide (also known as Titania). Titania is an inorganic solid white material that is not classified as hazardous according to the Globally Harmonized System of Classification and Labelling of Chemicals (GHS). The major problem in biological use of $\mathrm{TiO}_{2}$ nanoparticles, like other metal nanoparticles, is the high tendency of aggregation, which reduces contact surface area and biological activity. Among the solutions to overcome this problem is the use of $\mathrm{TiO}_{2}$ nanoparticles in combination with other materials in the form of nanocomposites $[12,13]$. Biopolymers are among the matrix compounds that are of interest in preventing the aggregation of metal oxide nanoparticles. Sodium hyaluronate biopolymer can be produced by a microbial method that is highly purified and suitable for medical applications [14].

\footnotetext{
* Corresponding author

e-mail: mohsen_safaei@yahoo.com
} 


\section{AIM}

The aim of this study is to use the Taguchi method to determine the optimal conditions for the synthesis of sodium hyaluronate-titanium dioxide nanocomposite with the highest anticancer activity.

\section{MATERIALS AND METHODS}

The sodium hyaluronate biopolymer was synthesized by Streptococcus zooepidemicus (IBRC10919) prepared from the Iranian Research Organization for Science and Technology (IROST) in a Brain Heart Infusion Broth (BHI broth) medium. The $\mathrm{TiO}_{2}$ nanoparticles were synthesized using the sol-gel method described in our previous study [15].

For the synthesis of sodium hyaluronate-titanium dioxide nanocomposite with the most anticancer activity, based on the Taguchi method in the Qulitek-4 software, nine different nanocomposites were synthesized by in situ method (Table 1). Thus, different levels of sodium hyaluronate biopolymer $(2,4$ and $8 \mathrm{mg} / \mathrm{ml})$ and various levels of $\mathrm{TiO}_{2}$ nanoparticles $(0.5,1$ and $2 \mathrm{mg} / \mathrm{ml}$ ) at stirring times of 30,60 and $90 \mathrm{~min}$ were compared to determine the optimal conditions for the synthesis of sodium hyaluronate-titanium dioxide nanocomposite.

Table 1. Taguchi design of experiments and results of anticancer activity of sodium hyaluronate-titanium dioxide bionanocomposites

\begin{tabular}{|c|c|c|c|c|c|c|c|c|c|c|}
\hline \multirow[t]{2}{*}{ Experiment } & \multicolumn{3}{|c|}{$\begin{array}{c}\mathrm{TiO}_{2} \\
(\mathrm{mg} / \mathrm{ml})\end{array}$} & \multicolumn{3}{|c|}{$\begin{array}{c}\text { Sodium } \\
\text { hyaluronate } \\
(\mathrm{mg} / \mathrm{ml})\end{array}$} & \multicolumn{3}{|c|}{$\begin{array}{l}\text { Stirring } \\
\text { time } \\
\text { (min) }\end{array}$} & \multirow{2}{*}{$\begin{array}{c}\text { Cell } \\
\text { growth } \\
\text { inhibition } \\
(\%)\end{array}$} \\
\hline & 2 & 4 & 8 & 0.5 & 1 & 2 & 30 & 60 & 90 & \\
\hline 1 & & 2 & & & 0.5 & & & 30 & & 40.52 \\
\hline 2 & & 2 & & & 1 & & & 60 & & 49.34 \\
\hline 3 & & 2 & & & 2 & & & 90 & & 36.19 \\
\hline 4 & & 4 & & & 0.5 & & & 60 & & 59.94 \\
\hline 5 & & 4 & & & 1 & & & 90 & & 65.25 \\
\hline 6 & & 4 & & & 2 & & & 30 & & 62.92 \\
\hline 7 & & 8 & & & 0.5 & & & 90 & & 50.23 \\
\hline 8 & & 8 & & & 1 & & & 30 & & 64.87 \\
\hline 9 & & 8 & & & 2 & & & 60 & & 68.89 \\
\hline
\end{tabular}

The MTT assay was applied to assess the anticancer activity of the synthesized nanocomposites on MCF-7 cell line prepared at the Pasteur Institute of Iran. For this purpose, the cells in the Dulbecco's Modified Eagle's Medium (DMEM) containing 10\% fetal bovine serum (FBS) and $1 \%$ penicillin-streptomycin were incubated in $\mathrm{CO}_{2}$ and humidity at $37^{\circ} \mathrm{C}$. The cells were separated from the flask by trypsin-EDTA and then $180 \mu \mathrm{l}$ of the prepared cell suspension containing $5 \times 104$ cells was poured into each well of a 96-well plate and cultured in the incubator for $24 \mathrm{~h}$. Next, $20 \mu \mathrm{l}$ of the suspension containing the nanocomposites was added to each well; the untreated wells were considered as controls. After $72 \mathrm{~h}$ of cell treatment with nanocomposite compounds, $20 \mu \mathrm{l}$ of MTT at a concentration of $5 \mathrm{mg} / \mathrm{ml}$ was prepared in Phosphate Buffered Saline (PBS) and added to each well. The surface of the plate was then covered and incubated for $4 \mathrm{~h}$ at $37^{\circ} \mathrm{C}$ with $5 \% \mathrm{CO}_{2}$. After this time, the supernatant solution of each well was replaced by $100 \mu \mathrm{l}$ of dimethyl sulfoxide (DMSO) and the plate was placed on a shaker for $10 \mathrm{~min}$. Ultimately, the optical density was read by ELISA reader at a wavelength of $570 \mathrm{~nm}[16,17]$. All trials of this study included three tests carried out in triplicate and the inhibitory level of cancer cell growth was determined using the following equation:

$$
\text { Cell growth inhibition }(\%)=\frac{\mathrm{ODc}-\mathrm{ODt}}{\mathrm{ODc}} \times 100 \%
$$

ODt: optical density of treated cells,

ODc: optical density of control cells.

The TESCAN scanning electron microscopy made in the Czech Republic was used to determine the distribution, shape and dimensions of nanoparticles and nanocomposites. Data analysis was performed using Qualitek-4 software.

\section{RESULTS}

The SEM images prepared from $\mathrm{TiO}_{2}$ nanoparticles and sodium hyaluronate-titanium dioxide nanocomposite are presented in Figure 1. The SEM images reveal that the nanoparticles were almost spherical with an average size of $23 \mathrm{~nm}$, which were partially agglomerated. The image of sodium hyaluronate-titanium dioxide nanocomposite shows the spread of nanoparticles on the surface of the biopolymer, which confirms the formation of the nanocomposite.
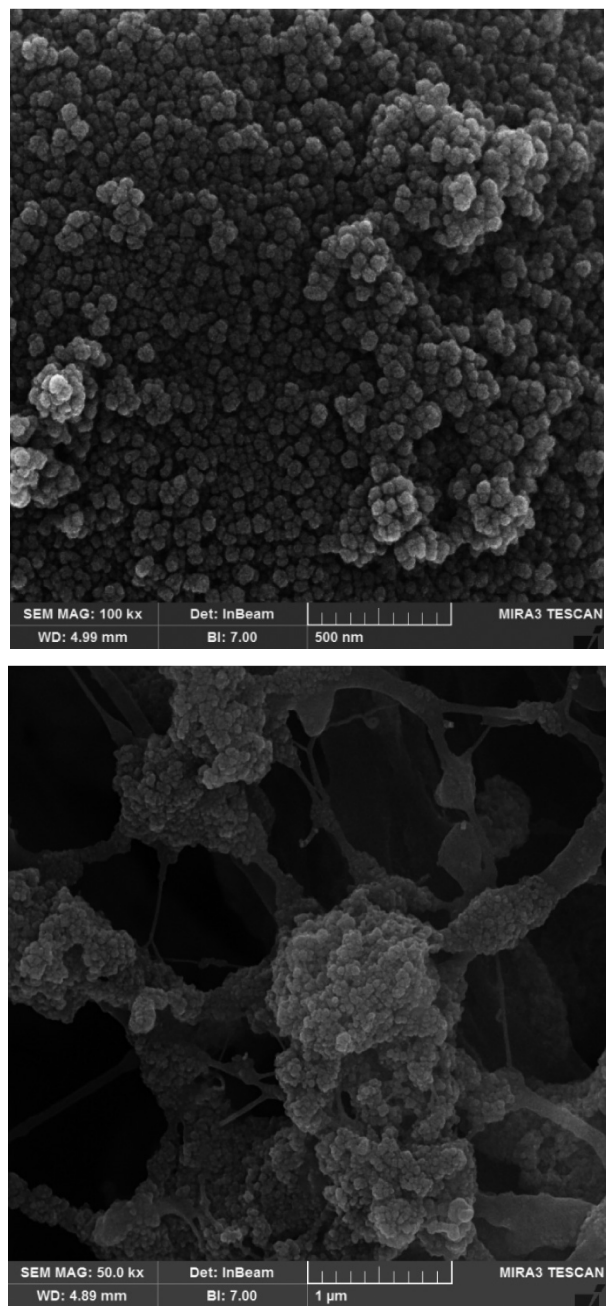

Figure 1. SEM images of $\mathrm{TiO}_{2}$ nanoparticles (up) and sodium hyaluronate- $\mathrm{TiO} 2$ nanocomposite (down) 
The cytotoxicity level of nine produced nanocomposites is presented in Table 1 . The results indicate that the nanocomposite synthesized with $8 \mathrm{mg} / \mathrm{ml}$ of titanium dioxide, $2 \mathrm{mg} / \mathrm{ml}$ of sodium hyaluronate and $60 \mathrm{~min}$ stirring time (experiment 9) have the highest inhibitory effect on cancer cell growth (68.89\%) while the lowest effect $(36.19 \%)$ is related to the nanocomposite synthesized in the conditions of experiment 3 ( $2 \mathrm{mg} / \mathrm{ml}$ of titanium dioxide, $2 \mathrm{of} \mathrm{mg} / \mathrm{ml}$ sodium hyaluronate and $90 \mathrm{~min}$ stirring time).

The effect of $\mathrm{TiO}_{2}$ nanoparticles, sodium hyaluronate biopolymer and stirring time at different levels on the inhibition of cancer cell growth by sodium hyaluronate-titanium dioxide nanocomposite is displayed in Table 2. The second level in all three investigated factors shows the highest effect in inhibiting the cancer cell growth. The effect of $\mathrm{TiO}_{2}$ nanoparticles, sodium hyaluronate biopolymer and stirring time on the structure of sodium hyaluronate-titanium dioxide nanocomposite at the highest levels in inhibiting the cancer cell growth is $62.70 \%, 59.82 \%$ and $59.39 \%$, respectively.

Table 2. Effect of different levels of factors on anticancer activity of sodium hyaluronate-titanium dioxide bionanocomposite

\begin{tabular}{|l|c|c|c|}
\hline \multicolumn{1}{|c|}{ Factors } & Level 1 & Level 2 & Level 3 \\
\hline $\mathrm{TiO}_{2}$ & 42.02 & 62.70 & 61.33 \\
\hline Sodium hyaluronate & 50.23 & 59.82 & 56.00 \\
\hline Stirring time & 56.10 & 59.39 & 50.56 \\
\hline
\end{tabular}

Table 3 reveals the interactions between $\mathrm{TiO}_{2}$ nanoparticles, sodium hyaluronate biopolymer and stirring time at different levels. The third level of sodium hyaluronate biopolymer and the second level of stirring time have the highest interaction $(53.44 \%)$ on inhibiting the cancer cell growth. The $\mathrm{TiO}_{2}$ nanoparticles at the third level and the stirring time at the second level demonstrate a significant interaction (18.04\%) in inhibiting the growth of MCF-7 cancer cells. The interaction between the third level of $\mathrm{TiO}_{2}$ nanoparticles and sodium hyaluronate biopolymer reveal the lowest effect on reducing the cancer cell growth (5.36\%).

Table 3. Interaction of studied factors on anticancer activity of sodium hyaluronate-titanium dioxide bionanocomposite

\begin{tabular}{|l|c|c|c|}
\hline \multicolumn{1}{|c|}{ Interacting factor pairs } & Column & $\begin{array}{c}\text { Severity Index } \\
(\%)\end{array}$ & $\begin{array}{c}\text { Optimum } \\
\text { conditions }\end{array}$ \\
\hline $\begin{array}{l}\text { Sodium hyaluronate } \\
\times \text { Stirring time }\end{array}$ & $2 \times 3$ & 53.44 & {$[3,2]$} \\
\hline $\mathrm{TiO}_{2} \times$ Stirring time & $1 \times 3$ & 18.04 & {$[3,2]$} \\
\hline $\mathrm{TiO}_{2} \times$ Sodium hyaluronate & $1 \times 2$ & 5.36 & {$[3,3]$} \\
\hline
\end{tabular}

Analysis of variance (ANOVA) of $\mathrm{TiO}_{2}$ nanoparticles, sodium hyaluronate biopolymer and stirring time for inhibition of cancer cell growth is shown in Table 4. The $\mathrm{TiO}_{2}$ nanoparticles and stirring time, respectively, have the most $(69.60 \%)$ and least $(7.47 \%)$ effects on inhibiting cancer cell growth. In addition, the sodium hyaluronate biopolymer

Table 4. Analysis of variance for anticancer activity of sodium hyaluronate-titanium dioxide bionanocomposite

\begin{tabular}{|l|c|c|c|c|c|c|}
\hline \multicolumn{1}{|c|}{ Factors } & DOF & $\begin{array}{c}\text { Sum of } \\
\text { Squares }\end{array}$ & Variance & $\begin{array}{c}\text { F-Ratio } \\
(\mathrm{F})\end{array}$ & $\begin{array}{c}\text { Pure } \\
\text { Sum }\end{array}$ & $\begin{array}{c}\text { Percent } \\
(\%)\end{array}$ \\
\hline $\mathrm{TiO}_{2}$ & 2 & 802.83 & 401.41 & 21.44 & 765.39 & 69.60 \\
\hline Sodium hyaluronate & 2 & 139.85 & 69.93 & 3.73 & 102.41 & 9.31 \\
\hline Stirring time & 2 & 119.59 & 59.80 & 3.19 & 82.16 & 7.47 \\
\hline
\end{tabular}

is also effective in reducing the growth of MCF-7 cancer cells by $9.31 \%$.

The optimal conditions for the production of sodium hyaluronate-titanium dioxide nanocomposite with the highest anticancer activity using the Taguchi method are predicted in Table 5. Based on the results, the second levels of $\mathrm{TiO}_{2}$ nanoparticles, sodium hyaluronate biopolymer and stirring time have the highest role in improving the inhibition of MCF-7 cell growth (with a contribution of $7.35 \%$, $4.47 \%$ and $4.04 \%$, respectively). Due to the average cell growth inhibitory level (55.35\%) under different experimental conditions and its growth reduction in optimal conditions $(15.86 \%)$, the cancer cell growth is expected to be inhibited by the nanocomposite synthesized in optimal conditions to $71.21 \%$.

Table 5. Prediction of optimal conditions for the synthesis of sodium hyaluronate-titanium dioxide bionanocomposite with maximum anticancer activity

\begin{tabular}{|l|c|c|}
\hline \multicolumn{1}{|c|}{ Factors } & Level & Contribution \\
\hline $\mathrm{TiO}_{2}$ & 2 & 7.35 \\
\hline Sodium hyaluronate & 2 & 4.47 \\
\hline Stirring time & 2 & 4.04 \\
\hline \multicolumn{2}{|l|}{} & 15.86 \\
\hline Total contribution from all factors & 55.35 \\
\hline Current grand average of performance & 71.21 \\
\hline
\end{tabular}

\section{DISCUSSION}

In the present study based on the Taguchi method, some nanocomposites were synthesized using different amounts of $\mathrm{TiO}_{2}$ nanoparticles, sodium hyaluronate biopolymer and different stirring times and were exposed to MCF-7 breast cancer cell lines in order to detect the strongest anticancer composition. The evaluation of the morphological characteristics and size of $\mathrm{TiO}_{2}$ nanoparticles and sodium hyaluronate-titanium dioxide nanocomposite with SEM confirms the synthesis of the nanoparticle and nanocomposite. The MTT test results indicated that the anticancer activity level of the studied nanocomposites varied from $36.19 \%$ to $68.89 \%$, and the nanocomposite produced in experiment 9 had the highest inhibitory effect on the cancer cell growth. Previous studies reported anticancer activity of $\mathrm{TiO}_{2}$ nanoparticles alone and in the structure of nanocomposites, which is consistent with the results of this study [18-20]. In addition, former researches have shown that the application of $\mathrm{TiO}_{2}$ nanoparticles in the form of nanocomposite can improve its anticancer activity [21,22]. Ren et al. [18] synthesized a nanocomposite consisting of doxorubicin as an anticancer drug and $\mathrm{TiO}_{2}$ nanoparticles to overcome breast cancer cells with multiple drug resistance. The electrostatic interactions caused the stability of the synthesized nanocomposite. The anticancer effects of nanocomposite on resistant MCF-7 cancer cell lines were investigated using MTT assay. Based on the results, the use of nanocomposite showed a 2.4-times more anticancer effect than doxorubicin. They stated that the doxorubicin-titanium dioxide nanocomposite at a controlled $\mathrm{pH}$ in releasing the drug could be used to overcome breast cancer cells exhibiting multiple drug resistance. 
The effective properties of nanoparticles have increased their use in cancer treatment. Nanoparticles can be applied to treat cancer through passive or active processes. A passive process has the advantage of enhanced permeability and retention (EPR). The nanoparticles are easily released through the damaged vascular system in cancer tissues and cause cancer cells to die. In addition to cancer cells, the inflamed tissue also has damaged vessels that easily are affected by the nanoparticles. Therefore, the passive activity of nanoparticles is not very accurate. In an active process, nanoparticles are functionalized to target precisely the cancer cells. In the research on the anticancer therapy, metal oxide nanoparticles were used directly against tumor cells in vitro and in vivo $[23,24]$. Despite various studies conducted in this regard, the mechanism of action of the nanoparticle effect on the cancer cells is unclear so far.

Gopinath et al. [25] examined the mechanism of the nanoparticle effects in inducing cell death in cancer cells and reported that the nanoparticles damage the membrane integrity of the cancer cells when bound to the membrane, and activate the $\mathrm{p} 53$ protein. The $\mathrm{p} 53$ protein is a known agent for the activation of proapoptotic genes, which then mobilize the bax, bad and bak proteins. These proteins cause leakage of the mitochondrial membrane and release of cytochrome c, which switches on Caspase 3 in a cascade reaction. Eventually, the Caspase 3 disrupts the nuclear membrane and causes DNA fragmentation. Simultaneously, the upregulation of Cmyc greatly enhances the apoptotic signals and down-regulates antiapoptotic genes of bcl2 and bclXL, which increases the incidence of apoptosis and thus the destruction of cancer cells.

\section{CONCLUSION}

The results showed that the $\mathrm{TiO}_{2}$ nanoparticles synthesized by the sol-gel method and sodium hyaluronate biopolymer produced by Streptococcus zooepidemicus were well combined together and the sodium hyaluronatetitanium dioxide nanocomposite was constructed with an optimal anticancer activity. The comparison of the anticancer activity level of synthesized nanocomposites using MTT assay showed that the nanocomposite synthesized in the conditions of experiment $9\left(8 \mathrm{mg} / \mathrm{ml}\right.$ of $\mathrm{TiO}_{2}$ nanoparticles, $2 \mathrm{mg} / \mathrm{ml}$ of sodium hyaluronate biopolymer and $60 \mathrm{~min}$ stirring time) had the maximum anticancer activity against the Michigan Cancer Foundation-7 (MCF-7) cell line. Due to the increasing incidence of cancer risk and the lack of effective anticancer compounds, we recommend evaluating the cytotoxicity of the synthesized nanocomposite in the conditions proposed in this study on different cancer cell lines and in normal cells.

\section{ORCID iDs}

Mohsen Safaei (Dhttps://orcid.org/0000-0003-3885-6640 Mojtaba Taran Dhttps://orcid.org/0000-0002-9927-3687 Mohammad Moslem Imani (Dhttps://orcid.org/0000-0002-3982-5216 Hedaiat Moradpoor (Dhttps://orcid.org/0000-0002-9161-8038 Amin Golshah (Dhttps://orcid.org/0000-0002-8167-7632 Prabhat Upadhyay (Dhttps://orcid.org/0000-0003-1432-6792

\section{REFERENCES}

1. Kumar L, Verma S, Prasad DN, Bhardwaj A, Vaidya B, Jain AK. Nanotechnology: a magic bullet for HIV AIDS treatment. Artif Cells Nanomed Biotechnol. 2015;43(2):71-86.

2. Mozaffari HR, Zavattaro E, Abdolahnejad A, Lopez-Jornet P, Omidpanah N, Sharifi R, Sadeghi M, et al. Serum and Salivary IgA, IgG, and IgM Levels in Oral Lichen Planus: A Systematic Review and Meta-Analysis of Case-Control Studies. Medicina. 2018;54:99.

3. Taran M, Etemadi S, Safaei M. Microbial levan biopolymer production and its use for the synthesis of an antibacterial iron (II, III) oxide-levan nanocomposite. J Appl Polym Sci. 2017;134(12): 44613.

4. Sharifi R, Khazaei S, Mozaffari HR, Amiri SM, Iranmanesh P, Mousavi SA. Effect of massage on the success of anesthesia and infiltration injection pain in maxillary central incisors: Doubleblind, crossover trial. Dent Hypotheses. 2017;8(3):61-4.

5. Mozaffari HR, Izadi B, Sadeghi M, Rezaei F, Sharifi R, Jalilian F. Prevalence of oral and pharyngeal cancers in Kermanshah province, Iran: A ten-year period. Int J Cancer Res. 2016;12(3-4):169-175.

6. Mozaffari HR, Payandeh M, Ramezani M, Sadeghi M, Mahmoudiahmadabadi M, Sharifi R. Efficacy of palifermin on oral mucositis and acute GVHD after hematopoietic stem cell transplantation (HSCT) in hematology malignancy patients: a metaanalysis of trials. Wspolczesna Onkol. 2017;21(4):299-305.

7. Parsa N. Environmental factors inducing human cancers. Iran J Public Health. 2012;41(11):1-9.

8. Brawley OW. Avoidable cancer deaths globally. CA Cancer J Clin. 2011;61(2):67-8.

9. Gopalan MR, Karunakaran V, Prabhakaran A, Jayakumar KL. Prevalence of psychiatric morbidity among cancer patients-hospitalbased, cross-sectional survey. Indian J Psychiatry. 2016;58(3):275-80.

10. Safaei M, Taran M. Optimized synthesis, characterization, and antibacterial activity of an alginate-cupric oxide bionanocomposite. J Appl Polym Sci. 2018;135(2):45682.

11. Shi J, Kantoff PW, Wooster R, Farokhzad OC. Cancer nanomedicine: progress, challenges and opportunities. Nat Rev Cancer. 2017;17(1): 20-37.

12. Weir A, Westerhoff P, Fabricius L, Hristovski K, Von Goetz N. Titanium dioxide nanoparticles in food and personal care products. Environ Sci Technol. 2012;46(4):2242-50.

13. Safaei M, Taran M. Fabrication, characterization, and antifungal activity of sodium hyaluronate- $\mathrm{TiO}_{2}$ bionanocomposite against Aspergillus niger. Mater Lett. 2017;207:113-6.

14. Boeriu CG, Springer J, Kooy FK, Van den Broek LA, Eggink G. Production methods for hyaluronan. Int J Carbohyd Chem. 2013:624967.

15. Safaei M, Taran M. Optimal conditions for producing bactericidal sodium hyaluronate- $\mathrm{TiO} 2$ bionanocomposite and its characterization. Int J Biol Macromol. 2017;104:449-56.

16. Arunkumar P, Vedagiri H, Premkumar K. Rapid bioreduction of trivalent aurum using banana stem powder and its cytotoxicity against MCF-7 and HEK-293 cell lines. J Nanopart Res. 2013;15(3): 1481.

17. Rezaei R, Mostafaie A, Gorgin Karaji A, Mansouri K. The effect of standardized extract of Echinacea Purpurea on cytotoxicity and proliferation of rat splenocytes. J Appl Biol Sci. 2015;9(2):19-22.

18. Ren W, Zeng L, Shen Z, Xiang L, Gong A, Zhang J, et al. Enhanced doxorubicin transport to multidrug resistant breast cancer cells via TiO2 nanocarriers. RSC Adv. 2013;3(43):20855-61.

19. Latha TS, Reddy MC, Muthukonda SV, Srikanth VV, Lomada D. In vitro and in vivo evaluation of anti-cancer activity: Shape-dependent properties of $\mathrm{TiO}_{2}$ nanostructures. Mater Sci Eng C. 2017;78:969-77.

20. Tong R, Lin H, Chen Y, An N, Wang G, Pan X, Qu F. Near-infrared mediated chemo/photodynamic synergistic therapy with DOXUCNPs@mSiO2/TiO2-TC nanocomposite. Mater Sci Eng C. 2017;78: 998-1005.

21. Yamaguchi S, Kobayashi H, Narita T, Kanehira K, Sonezaki S, Kubota Y, et al. Novel Photodynamic Therapy Using Water-dispersed $\mathrm{TiO}_{2}$-Polyethylene Glycol Compound: Evaluation of Antitumor Effect on Glioma Cells and Spheroids In vitro. J Photochem Photobiol. 2010;86(4):964-71. 
22. Chakra CS, Rajendar V, Rao KV, Kumar M. Enhanced antimicrobial and anticancer properties of $\mathrm{ZnO}$ and $\mathrm{TiO}_{2}$ nanocomposites. 3 Biotech. 2017; 7(2):89.

23. Danhier F, Feron O, Preat V. To exploit the tumor microenvironment: passive and active tumor targeting of nanocarriers for anti-cancer drug delivery. J Control Release. 2010;148(2):135-46.
24. Vinardell MP, Mitjans M. Antitumor activities of metal oxide nanoparticles. Nanomaterials. 2015;5(2):1004-21.

25. Gopinath P, Gogoi SK, Sanpui P, Paul A, Chattopadhyay A, Ghosh SS. Signaling gene cascade in silver nanoparticle induced apoptosis. Colloids Surf B Biointerfaces. 2010;77(2):240-5. 